\title{
AMS INSIGHT_Absorbable Metal Stent Implantation for Treatment of Below-the-Knee Critical Limb Ischemia: 6-Month Analysis
}

\author{
Marc Bosiers · Patrick Peeters · Olivier D'Archambeau • Jeroen Hendriks • \\ Ernst Pilger · Christoph Düber · Thomas Zeller · Andreas Gussmann · \\ Paul N. M. Lohle - Erich Minar • Dierk Scheinert - Klaus Hausegger • \\ Karl-Ludwig Schulte $\cdot$ Jürgen Verbist $\cdot$ Koen Deloose $\cdot$ J. Lammer
}

Published online: 17 March 2009

(C) Springer Science+Business Media, LLC 2009

\section{Erratum to: Cardiovasc Intervent Radiol \\ DOI 10.1007/s00270-008-9472-8}

The list of authors for the article noted above was included as an Appendix in the manuscript, but the co-authors were not included or identified as co-authors on the submitted title page. For publication purposes, the required format is to include all co-authors on the title page of a manuscript submission. Due to the alternate submitted format, the article has been published with only one name listed as a contributing author underneath the article title.

The use of this format does not allow the contributing authors to receive credit for citations to the paper, unless an erratum is published which lists all of the contributing authors.

The online version of the original article can be found under doi: $10.1007 / \mathrm{s} 00270-008-9472-8$.

\footnotetext{
M. Bosiers $(\square) \cdot$ K. Deloose

Department of Vascular Surgery, AZ St-Blasius,

Kroonveldlaan 50 9200, Dendermonde, Belgium

e-mail: marc.bosiers@telenet.be

P. Peeters $\cdot$ J. Verbist

Imelda Ziekenhuis, Bonheiden, Belgium

O. D'Archambeau · J. Hendriks

Universitair Ziekenhuis, Antwerpen, Belgium

E. Pilger

Medizinische Universität, Graz, Austria

C. Düber

Universitätsklinikum, Mainz, Germany

T. Zeller

Herzzentrum, Bad Krozingen, Germany
}

All contributing authors for this article are listed below.

M. Bosiers, AZ St. Blasius, Dendermonde, Belgium

P. Peeters, Imelda Ziekenhuis, Bonheiden, Belgium

O. D'Archambeau, Universitair Ziekenhuis, Antwerpen, Belgium

J. Hendriks, Universitair Ziekenhuis, Antwerpen, Belgium

E. Pilger, Medizinische Universität, Graz, Austria

Ch. Düber, Universitätsklinikum, Mainz, Germany

Th. Zeller, Herzzentrum, Bad Krozingen, Germany

A. Gussmann, Humaine Kliniken, Bad Saarow, Germany

P. N. M. Lohle, St. Elisabeth Ziekenhuis, Tilburg, The Netherlands

E. Minar, AKH, Vienna, Austria

D. Scheinert, Universitätsklinikum, Leipzig, Germany
A. Gussmann

Humaine Kliniken, Bad Saarow, Germany

P. N. M. Lohle

St. Elisabeth Ziekenhuis, Tilburg, The Netherlands

E. Minar · J. Lammer

AKH, Vienna, Austria

D. Scheinert

Universitätsklinikum, Leipzig, Germany

K. Hausegger

A.ö. Landeskrankenhaus, Klagenfurt, Austria

K.-L. Schulte

Krankenhaus Herzberge, Berlin, Germany 
K. Hausegger, A.ö. Landeskrankenhaus, Klagenfurt, Austria

K. L. Schulte, Krankenhaus Herzberge, Berlin, Germany
J. Verbist, Imelda Hospital, Bonheiden, Belgium

K. Deloose, AZ St. Blasius, Dendermonde, Belgium J. Lammer, AKH, Vienna, Austria 